
\title{
25 Research Suare \\ The Effects of Home-Grown Rule on Efficiency of Sports Teams : Evidence from English Premier League
}

\section{Seungmin Shin}

Seoul National University College of Law: Seoul National University School of Law

Changhee Kim ( $\nabla$ ckim@inu.ac.kr)

Incheon National University https://orcid.org/0000-0002-6087-3132

\section{Research}

Keywords: Data envelopment analysis, English premier league, Football, Home-grown regulation, Efficiency

Posted Date: February 16th, 2021

DOI: https://doi.org/10.21203/rs.3.rs-196964/v1

License: (c) (i) This work is licensed under a Creative Commons Attribution 4.0 International License. Read Full License 


\section{Abstract}

Research question

The English Premier League, one of the most successful football league, is on the verge of losing its competitive edge due to Home-grown regulation proposal. This study focuses on the effects of this regulation on football clubs' financial and operational efficiency.

Research methods

To accurately measure the effects of these measures, Data Envelopment Analysis (DEA) technique was used to 10 different Premier League Clubs spanning 7 years. Data of 10 clubs that have never been relegated were collected over 7 years.

Results and findings

Efficiency score spread shows that clubs were seriously affected in efficiency in adjacent season after the implementation of the Home-grown regulation. Clubs were financially impacted due to rising cost of required Home-grown players, further depriving its financial footholds. Also, efficacy of this regulation was not effective as the Home-grown players did not gain much playing time in the field.

Implications

Football Association proposes further strengthening the Home-grown regulation in the future seasons. This study concludes that proposed home-grown regulation will further impact the football clubs financially as it was evident from the efficiency modeling in the study.

\section{Introduction}

Every business has its innate pursuit, and for football clubs, it is to increase its win-rate in order to elevate its status and maximize profit. Football clubs that are financially inefficient or unstable face difficulties in signing players and finalizing its team, which results in an adverse effect on the win-rate of the club itself. Thus, football clubs strive to achieve field success, and this pursuit has implications in terms of business decision-making (Morrow, 2003). Therefore, according to Szymanski and Kuypers (1999), the connection between sports and financial activities greatly affects the competitiveness of football clubs.

However, from the league-perspective, other goals exist alongside financial efficiency. As noted by Amenta et al (2012), "the young athlete is another area of interest in which political institutions have requested sport governing bodies to be active in guiding professional teams" (p. 28). While sound financial structure is still important, bringing up the next generation of players and ultimately contributing to the development of national sports are held as a primary mission as a sports league. For this reason, a sports league's regulating body imposes regulations upon its sports clubs to ensure that this primary mission can be achieved. These regulations often involve restrictions on the sport clubs' financial 
structure to check and balance the overall prosperity of the sport. In fact, according to Dalziel et al (2012), UEFA is keen on maintaining healthy balance in the league, including but not limited to competitive advantage of each league and the usage of club-trained players. In the case of football, Union of European Football Association (UEFA)'s Financial Fair Play (FFP) and Football Association (FA)'s Homegrown regulation are examples of the restrictions imposed to promote sustainability of the sports league.

Despite the well-meaning intentions of these regulations, they often tend to be detrimental to clubs financially, performance-wise, as well as in terms of providing entertainment to its fans. Certain regulations act in ways that result in redundantly increasing the players' salaries, thereby greatly affecting the sports clubs' profits and making the sports clubs financially inefficient. At present, the England Football Association's Home-grown rule has fallen under the spotlight for its negative financial impact on the football clubs under the English Premier League (EPL) as "FA chairman Greg Dyke wants to introduce tougher rules to improve opportunities for home-grown players" (p. 1) (Skysports, 2015a) for the 20162017 season. The Home-grown rule is criticized by many, because "The rule hurts many people: the players that are unable to earn the Premier League's high salaries and level of notoriety; the clubs that are unable to employ the best possible teams of players; and the fans that are unable to witness the greatest possible football” (p. 260) as stated by Henderson (2011) of the Brooklyn Journal of International Law.

In light of this current movement, this study investigates the effect of the FA's Home-grown regulation on the financial efficiency of the football clubs by providing a chronological overview of the financial stability and efficiency of the football clubs before and after the implementation of the Home-grown regulation, which will be analyzed using data envelopment analysis (DEA). In the next section, we will provide background information on the English Premier League and the FA's Home-grown regulation, followed by a literature review and methodology for analyzing the financial efficiency of the football clubs. Part 4 will present the results of the analysis, and part 5 will conclude the paper with a discussion on the implications of the results.

UEFA and FA has its own guidelines for the Home-grown regulations. Although they are one the same platform in broad strokes, their characteristics differ in regulation matter. Compared to the FA's Homegrown regulation, UEFA's provisions are more of a recommendation.

This study focuses on the Football Association (English Football governing body)'s implementation of the Home-grown regulation. Although UEFA implements similar to the Home-grown regulation, this regulation is applied for European cup competitions such as UEFA Champion's League, and UEFA Europa League (formerly UEFA cup) (Gardiner and Welch, 2011). Among the clubs analyzed in this study, the clubs that regularly participated in European competition are Manchester United, Arsenal, Liverpool, and Chelsea. Therefore, it deemed much more fit to study effect of FA's Home-grown regulation rather than the UEFA's one.

In addition, UEFA's Home-grown regulation on individual football leagues remained as recommendation. According to Gardiner and Welch (2011), UEFA "recommended that national associations adopt similar rules for their own domestic leagues" (p. 776). Therefore, in the scope of this study, it seems much more 
pertinent to focus on FA's Home-grown regulation and the timeframe of 10-11 season for this study aims to find out about the effect of The Home-grown regulation on individual clubs.

Review on English Premier League and FA's Home-grown regulation

The English Premier League (EPL) is by far one of the most successful league in both performance and earnings. It is also reported as the most lucrative league in terms of players' salaries and revenues. According to Bullough and Mills (2014), "[the EPL] has grown into a global phenomenon that is followed by millions of fans around the world" (p. 637) and thanks to this global reach, the EPL's "most recent television rights deal saw a 71\% increase in value to 3 billion pounds over three years" (p. 638) (Bullough and Mills, 2014) which is an unprecedented, record-breaking amount for any league. The popularity of the EPL has significantly increased the league's income generation through TV rights, sponsorships, gate receipts, and corporate hospitality, and this income is relatively equally distributed among the league's football clubs through various policies and programs. According to the Premier League (2015), the distribution of earnings between clubs "resulted in a ratio of 1.53:1 between of the club finishing top and that finishing bottom in $2014 / 15^{\prime \prime}$ (p. 1). Thanks to this distribution of wealth, the football clubs under EPL have stronger financial foundations than those in any other leagues, and with this financial foundation, each EPL football club dedicates its excess earnings to signing top players from around the world.

While players can be and are brought up through the youth academy system run by each football club, raising players requires patience and long-term investment (Nesti and Sulley, 2014). Thus, if financially possible, it is no surprise that clubs prefer to sign ready-made players who can bring immediate return. According to Bullough and Mills (2014), elite clubs spend over 40 million pounds in their academies annually. However, it has been suggested that only 23-25 English players aged 23 years or under enter the EPL each year (Bullough and Mills, 2014). Fueled by increased purchasing power and a short-term win-at all-costs culture, English football clubs have been known to sign on ready-made star players despite the high cost. (Bullough and Mills, 2014) Typically, ready-made players are in their prime age with performance proven in EPL or other top-tier leagues such as La Liga and Serie A.

According to Quirk and El Hodiri (1974), football club managers act as a profit maximizer and it is in the interest and efficiency of football clubs to sign players that can be the most effective with least cost. After all, for football clubs to use ready-made players benefit in the perspective that these players tend to be qualified and impose lesser risk on failure of implementation. However, in terms of holistic perspective of league, this type of profit-maximizing behavior imposes problems in that, investing billions of pounds into signing ready-made players is taking bricks off from the academy of each club itself (Bullough and Mills, 2014). Eventually, youth system will suffer from detrimental effect and thereby adversely affecting the host country itself: England. Bullough and Mills (2014) describe this phenomenon in this manner:

"Taken together, these factors have been largely responsible for reshaping the landscape of European football with discernible increase in the number of players migrating to league outside their own national 
association. In doing so, this restructuring effect has led to "migration that patterns that appear to be having a negative impact on indigenous player development" (p. 638). (Bullough and Mills, 2014)

However, its symptoms will be hard to observe, for the association and the club will not have any covert problem funding for signing ready-made players, due to their continuously increasing broadcast fees and incomes (Barros and Leach, 2006b). It will not be visible from performance standpoint, for these players are not likely to adversely affect the performance or quality of the league and football. Its talentdiminishing effects will be rather visible from the international tournaments involving national teams such as FIFA World Cup (Jewell, 2014). In fact, this phenomenon has plagued the English national team for decades. Unlike its league stature, English football has suffered massive depreciation in the international tournaments (Taylor, 2008).

One prime example suffering from this effect would be, ironically, English Premier League itself. According to the UEFA (2016), the English Premier League stands at the third most skilled league in the world. Considering the fact that UEFA holds one of the most advanced football leagues, there is no doubt that English Premier League is one of the most successful and accomplished league in the world. Yet, England's football in World Cup has been disappointing. In fact, Spain, which holds the first spot in league rankings, won the FIFA World Cup in 2010, and Germany, which holds second in League ranking, won FIFA World Cup in 2014. However, unlike these countries, England, which holds third, did not make through round of 16 in 1998 and 2010, and round of 8 in 2002 and 2006, making its reputation mismatched with results.

FA's adoption of Home-grown rule is focused on these realities that "pipeline for young Home-grown talent is still broken" (p. 1) (The FA, 2016). The purpose of this very regulation is to "create as many opportunities as possible for young Home-grown talent to compete at the highest level" (p. 1) thereby stimulating growth in youth academies (ibid). This, in turn, is expected to help England to achieve higher position in international competitions such as FIFA World Cup. The Home-grown regulation aims to fix such phenomenon by raising younger, indigenous athletes by requiring the usage of these players in the well-infrastructured league.

In England, as Henderson (2011) asserts, clubs could sign any player around the globe without any restriction until the 2009-2010 season. However, starting from 2010-2011 season, the regulation was in place to restrict foreign players to 17 players in 25 people roster. Each team is therefore required to submit the 25 player roster comprised of players 21 years old or older. This regulation, for it required the certain level of English players, propelled the signing fee of such players to skyrocket, burdening the club and the league greatly.

However, even after these power implementations were in place, England's international competition did not improve. In 2014, England failed to qualify from the group stage, putting its team in abysmal situation. In light of this disappointing result with strong league status, FA is seeking to harden the Homegrown regulation. The details of regulation, reported by Chosun Ilbo (2015), are: first, to restrict non-EU players to EPL by tightened requirements for work-visa through restricting the maximum FIFA rank of 
originating country from 70 to 50 and drastically increasing the number of A-matches the athlete has to compete in. Second, FA tightened the regulation by raising the required number of home-grown players from currently 8 to 12 out of 25 players-roster starting from 2016 incrementally and proposing stricter home-grown status. Currently, if a player is registered to English or Welsh club before he turns 18, he is given the status. However, under the new regulations, a player must be registered before the age of 15 .

In other words, under the Home-grown regulation, the football club will need to increase its dependence on English players. With the toughened the status of English players, there will be an increase in the scarcity of English Players in the league as some players will lose their status as home-grown players. Prime examples of this would be Morgan Schneiderlin (Everton) and Cesc Fabregas (Chelsea). According to Skysports, "Midfielder Schneiderlin has been with Southampton since 2008 when he joined as an 18year-old from Strasbourg, France (2015b)" (p. 1). With new toughened rule, he will lose his status as a player has to be signed in a club at age of 15 . Cesc Fabregas falls under the same category as he joined Arsenal at the age of 16 (Skysports, 2015b). With these effects, the cost to sign an English player will skyrocket, as English players will be of scarcity in the market.

Overall, the Home-grown regulation is obviously on the way to increase burden for not only football clubs, but also to fans, the regulatory agency, and to the entire league as well. In due course, it will prove to be detrimental to the financial situation of the league. It is in light of this situation that this study attempts to measure inefficiency that the Home-grown regulation imposes on the football clubs and football as a sport using data envelopment analysis (DEA) technique.

\section{Literature Review, And Analytical Model}

\section{Literature Review on Analytical Model}

This study utilizes the data envelopment analysis (DEA) model in determining the effect of the Homegrown regulation on the EPL football clubs' financial efficiency. In formulating a model for DEA, it is crucial to set proper input factor, output factor and decision making unit (DMU) to adequately show the efficiency of respective DMUs. The following previous literature on the efficiency of English football clubs have been reviewed for guidelines in deciding which factors to include in input and output factors, and in deciding the DMUs.

Barros and Leach (2006a) uses league points, average attendance, and turnover as outputs. and the number of players, player's wage, and facility cost as inputs in evaluating the performance of EPL using DEA. As DMUs, 12 teams that were not relegated between the seasons from 1998-99 to 2002-03 were chosen, resulting in 60 DMUs (12 teams over 5 years). Meanwhile, Guzmán and Morrow (2007) set points earned, turnover as outputs to account for commercial and playing factor, and staff wage including those of the players as well as the director, managers and coaching staffs and operating expenses as input factors in calculating the efficiency and productivity of EPL football teams. Espitia-Escuer and GarciaCebrian (2010) applies player's individual ability tendency and physicality as input factors and the number of games played and the number of players for output factors. Haas (2003) chose remuneration 
for managers and players as input factor and earned points (for performance measure) and turnover (for franchise's financial success) as output factors. Guzmán (2006) uses similar input and output factors in that it uses profit and expense including specified standards as wage and administrative expense as input factors, and for output factor, turnover including all the matchday revenue and broadcast revenue. Table 2 summarizes the input and output factor used in the literature review.

Based on this literature review, the input and output factors for this study have been decided as follows. First, the operating cost and net asset were chosen as input factors. Operating cost includes the club's financial burden and activities, including, but not confined to, players' salaries, transfer fees, and various maintenance fees. The operating costs of a club reflects the comprehensive well-being of the club, providing the information about its financial activities. The net asset is the second input factor. Although financial activities primarily affect the clubs' financial health, the assets that clubs own and utilize tend to have a significant impact on the financial activities themselves. For example, the stadium, which is the primary asset for most clubs, directly influences the matchday revenue, which directly affects the turnover and operating profit. Three factors were chosen as output factors. In all of the literature reviewed, earned points were considered an important output factor, which signifies the performance of a club. The club's annual turnover was chosen as the second output factor since it represents and measures financial success of the club, and possibly the overall state of the club. As the final output factor, operating profit was chosen to reflect the overall cost spent in running the football club, which will allow us to see the efficiency of the club's management. Also, in this paper, authors have included both the number of players and operating expenses as factors for following reasons. In this paper, we wanted to assess how regulation requiring a certain number of home-grown players on the team unfairly influences the clubs by giving home-grown players undeserved advantages not only in terms of signing bonus but in terms of wage level as well. In other words, with similar wage levels, clubs are now less able to recruit quality players than before, affecting both their wage expense as well as the size of the squad. With this in mind, we wanted to assess how the home-grown rules also affect the wage levels of players by evaluating both wages and the number of staff members as input variables. In addition, the authors carried out the analysis multiple times by singling out and using different output factors. In order to see the performance management of the football clubs, the authors also did a separate analysis using points earned as the output factor. The authors conducted separate analyses using operating profit and turnover as output factors respectively by employing the same method as above. Conducting multiple analyses with different output factors allowed us to see the efficiency of the clubs' performance, which is measured by each of the output factors. With this in mind, we wanted to see how the Home-grown regulation affected clubs both from a financial standpoint and a performance standpoint.

In addition, there are literatures that include both wages and number of staff members as factors. As mentioned in the literature review part, Barros and Leach (2006) discusses the importance selecting the proper input and output measures, and therefore, includes both players' wages and the number of staff members as the output factors to measure the performance of a team in the analysis. Moreover, in a different paper, Barros and Santos (2003) uses both the salaries of the staff and the number of staff members as the input factors for the analysis. Various studies have also highlighted and included the 
number of staff as its input; for example, Barros (2003) included the number of trainers in assessing the efficiency of training activities of sports federation; Espita-Escuer (2010) included the number of players listed in the squad throughout the season to measure the efficiency of UEFA Champions Leagueparticipating clubs. Following these studies, we included both the wages and the size of staff to see how the Home-grown regulation affects the wage negotiation for the staff as well.

The descriptive statistics for clubs' wages and for the number of staff members also show that each of the factors had a different impact on the efficiency of the team, thus implying a weak correlation between the two variables and thus, implying that they are quite independent from each other. For these reasons, we believe that using both clubs' wages and the number of staff members are variables that are helpful in seeing how the Home-grown regulation negatively affects clubs in negotiating players' salaries.

In order to see how input factors decided affected the different measurements of performance, this study also chose to conduct independent and separate analysis by singling out and using different individual output factors such as points earned, operating profit and turnover. This analytical consideration allowed the author(s) to trace the correlation between each output factors and input factors, making the study more meaningful.

In selecting the DMUs, author(s) have observed 10 teams that were not relegated throughout the seasons from 2007-08 to 2013-14, taking into account that major provisions of the Home-grown regulation took effect during the 2010-2011 season. The 10 football clubs chosen for analysis are Arsenal, Aston Villa, Chelsea, Everton, Fulham, Liverpool, Manchester City, Manchester United, Sunderland, and Tottenham Hotspur, as they are the only teams that were not relegated throughout the chosen periods, which make them better qualified for DEA comparison. In addition, "first division teams were chosen rather than those in other divisions because of their economic and social relevance and due to the abundance of available statistics" (p. 25). (Garcia-Sanchez, 2007)

The chosen seasons for analysis includes 3 years before the Home-grown regulation was strictly implemented and 3 years after it was implemented in order to chronologically compare the effect of the regulation imposed. Unfortunately, the data for 2014-15 season was not included due to financial reporting deadline for UK companies at the time of this study. For the comparison, authors have included clubs that were not relegated during the observed time period, selecting 10 DMUs per year. The analysis compares the efficiency scores of the chosen teams over the 7-year period. This study followed the recommended DMU selection proposed by banker et al. (1984), the recommended minimum of the Data Envelopment Analysis technique. Furthermore, according to Nyhan\&Martin (1999), the appropriate number of input and output variables for DEA should be determined based on the number of DMUs. This is because the increase in variables for DEA results in the increase in efficient DMUs and this hinders identification of inefficient DMUs. Cooper et al. (2004) stated that the number of DMUs should be triple the sum of the number of input and output variables for DEA, and Boussofiane et al. (1991) mentioned that the number of DMUs should be larger than the product of the numbers of input and output variables. The number of DMUs and the numbers of input and output variables used in this study are 10, 2, and 1, 
respectively, and thus this study meets the requirement stated in Cooper et al. (2004) as well as in Boussofiane et al (1991). Thus, the number of variables and DMUs used in this study is deemed appropriate for DEA.

Originally, there has been a controversy between Cooper et al. (2004) and the Boussofiane et al. (1991) rule on number of DMUs required for the analysis. Therefore, in this research, author(s) discreetly approached the matter in order to satisfy both Cooper et al. (2004) rule, which stated that the number of DMUs to be equal or greater than the three times the sum of the number of input factors and output factors, and the Boussofiane et al. (1991) rule, which stated that the number of DMUs to be equal or larger than the product of the number of input factors, and the number of output factors. First, author(s) designed the original model derived from the multiple literature reviews. In this model, the operating cost and and net asset have been used as input factors, while points earned, operating profit, and turnover have been used as the output factor. Barros and Leach (2006a) has used net asset as the input factor in the research, while Guzman and Morrow (2007) has used the various cost as the input factor. Also, Guzman and Morrow (2007) has used the turnover and points earned as the output factor. Thus, this model contained 2 input factors, and 3 output factors as shown in the figure 1.

However, taking into account the fact that this research uses 10 DMUs, this model satisfies the Boussofiane et al. (1991) rule but does not satisfy the Cooper et al. (2004) rule. In compliance with the Cooper et al. (2004) rule, the original model would have to have at least 18 DMUs, for 2 input factors and 3 output factors. However, in the scope of this research, this was impossible to achieve due to the lack of DMUs that satisfied both homogeneity and comparability within the group of DMUs. This is due to the unique characteristics that Premier League clubs possess and the unbridgeable financial difference between Premier League teams and EFL Championship Teams (second division). Therefore, in this research, author(s) intentionally limited the DMUs to the teams that have never been relegated during the proposed 7-year timeframe. We suspected and confirmed that if a club were to be relegated in any point during the timeframe, the financial impact of the relegation would seriously impact the homogeneity of the DMUs. This claim is substantiated by many articles and policies including the article from Daily Mail by Alex Miller.

According to Alex Miller, in 10-11 season,

"Average Premier League wages have reached £22,353 a week - before lucrative bonuses - or £1.16million a year."

"Average Championship earnings are $£ 4,059$ a week ( $£ 211,068$ a year), less than a fifth of players one division above."(Miller, 2011)

As shown in the figure, players wage alone shows five-times difference between the leagues, rendering the simple comparisons meaningless. Other aspects of financial differences are even more striking. Due to the TV Broadcasting right deal that Premier League struck with Skysports and others, the gap is due to 
be widened. This phenomenon is best shown by how much the Championship teams are wanting to the be promoted.

"The stakes could scarcely be higher. With a $£ 1.7 \mathrm{bn}$ pot of gold waiting at the finish line, the incentive to reach the Premiership has never been greater. The new Premier League television deal, ratified in May, means that the three teams to be promoted from the Championship will get their hands on a jackpot that will have chairmen drooling." (James, 2006)

However, the gap is widening. According to BBC, "The Premier League has sold television rights to its games for a record $£ 5.136 \mathrm{bn}, 71 \%$ above last time." (BBC, 2015). This TV rights fee will be distributed the Premier League clubs, making the turnover gap between two leagues even more bigger, quite possibly to incomparable level. Premier League clubs, with much higher turnover, are able to operate on expensive stadiums, players and higher operating cost.

Therefore, in the interest of the proper usage of DEA, it was deemed highly unsuitable to compare the Premier League teams with relegated teams or Championship teams. It was very clear that relegated teams, even for a one-time relegation, did not have the same means and measures to compete financially with Premier League teams.

For the homogeneity and comparability of the DMUs, it was not only inevitable, but also necessary to only include the teams that remained in the Premier League during the observed seasons. Therefore, as described in the Figure 2, author(s) created 3 different models, in which, each model contained 1 different outputs with 2 shared input factors. Following shows the three models in compliance with both Cooper et al. (2004) rule and Boussofiane et al. (1991).

First model, as shown, uses points earned as the output factor, operating cost and net asset as the input factor. Second model, on the other hand, uses operating profit as the output factor, while using the same input factors as the first model. Third model shares the input factor with first and second model, while using turnover as the output factor. The analytical results of each model as DEA scores are described in the Table 5 in the part 4 of this paper.

After setting three models, author(s) performed Kruskal Wallis one-way ANOVA nonparametric test at 05 significance level in order to determine the model that is best suited for the analysis. Result showed that the model 1 of the revised model which incorporates points earned as the output factor, and original model are statistically same. The result of the pairwise analysis is shown in the figure 3 and the statistical calculation is shown in the table 3 .

Each row tests the null hypothesis that the Sample 1 and Sample 2 distributions are the same. Asymptotic significances (2-sided tests) are displayed. The significance level is .05

Therefore, in this research, author(s) will incorporate the first model (point-earned) model to further analysis of the impact that the Home-grown regulation has on each football club. 


\section{Analytical Model and Data Gathering}

The financial data necessary for DEA were gathered from each club's annual investor relations reports, and other data such as points earned were gathered from the Barclays English Premier League website.

\section{Methodology}

\section{Semi-Oriented Radial Measure(SORM)}

DEA is a method to measure relative efficiency based on input and output variables. The advantage of DEA is that there is no need for defining the relative importance of the input and output variables to allow the simultaneous analysis of multiple variables. The Charnes-Cooper-Rhodes (CCR) model and the Banker-Charnes-Cooper (BCC) model are the two major models for DEA, where the CCR model assumes a constant return to scale and the BCC model, variable return to scale. As the increase in input variables does not necessarily increase productivity in this study, the BCC model was considered a better fit for this study.

However, our data set has some negative values in output variables. In this reason, we cannot use the normal DEA method but have to use Semi-Oriented Radial Measure(SORM) for evaluation of football clubs in EPL. SORM uses the absolute value definition and proposes a model that can deal with negative data in its datasets (Emrouznejad et al., 2010). This model can be applicable to non-radial slacks of datasets with positive values and negative values. The most important concern of SORM is that it separates the negative and positive values parts from the original variables, containing negative data, and then utilizes the absolute value to change the negative value to the positive value part. DEA can be also divided into output-oriented DEA and input-oriented DEA: output-oriented DEA explores how much output needs to be increased for better efficiency whereas input-oriented DEA evaluates how much input must be decreased for better efficiency. As the football clubs analyzed in this study aim to increase their efficiency scores, output-oriented VRS-SORM model proposed by the Emrouznejad et al. (2010) with positive and negative values in input and output variables was used.

\section{Results}

\section{Chronological analysis of DEA result: Change in the efficiency}

The DEA was performed on the data of the 10 teams over the 7-year period. According to Charnes et al. (1978), Banker et al. (1984), DMU is at its efficient state at the efficiency score of 1 . The following graph shows the changes in the efficiency score of each of the 10 clubs by season.

Following is the result from the original model,

However, due to the limitations regarding the Cooper et al. (2004), author(s) used the 3 models that utilizes 2 input models and 1 output model, and the first of those models has been used for analysis. 
Following is the extensive result from each model.

With the analysis above, the author(s) used the first model, noted model (1), as the subject of analysis. With this, following figure shows the fluctuations of efficiency for each club before and after the implementation of the Home-grown regulation.

Two things can be inferred based on the figure above based on the figure above. While some of the clubs showed fluctuations within limits, the major trend of the efficiency scores was an overall drop pattern starting from the 10-11 season. This trend was even more conspicuous for Tottenham Hotspur, Chelsea, Aston Villa and Arsenal, which showed unparalleled and unprecedented drops in their efficiency scores. Also, unlike the relatively concentrated and uniform pattern of the efficiency scores of the football clubs prior to the 10-11 season, the trend seemed to dive and diverge starting from the 10-11 season. These drops in the efficiency scores for the most clubs can be attributed to the universal application of the Home-grown regulation starting from 10-11 season. These drops in efficiency is also shown by the average DEA scores of the football clubs. Following shows the overall trend of the average DEA scores of the EPL clubs used for this research.

In this figure, it clearly shows that the clubs, in general, shows significant and unparalleled drop in efficiency after the 10-11 season when the Home-grown regulation has been implemented. Also, the impact is never fully recovered until much later seasons, showing the lasting impact that the regulation has on each club. This shows that it requires much more asset and operating cost to achieve the same league scores than the Home-grown regulation was implemented. This is due to the fact that signing quality English players has become much more burdensome and difficult.

On a more individual level, clubs seemed to have been affected to varying degrees. However, there are some unified trends among the clubs that show the drops in efficiency starting from 10-11 season. There are, of course, clubs that do not show the drops in efficiency score in 10-11 season or after. Yet, these clubs are more adversely or favorably affected by other factors, which will be further elaborated. Following is the clubs that are affected by the Home-grown regulation.

We can see that Tottenham Hotspur, Aston Villa, and Manchester United were efficiently run prior to 10-11 season. However, they took a significant turn starting from the 10-11 season. Aston Villa, for example, showed continuous drop in the efficiency score after the implementation of the Home-grown regulation in the 10-11 season, suggesting that this club was significantly impacted by this very regulation. Tottenham Hotspur showed a much more drastic drop after the implementation of the Home-grown regulation. Before the 10-11 season, this club showed outstanding efficiency scores, hinting that the overall management created maximum output with minimal input. However, when the regulation was put in place, its efficiency dropped significantly, recovering seasons after the initial drop.

Other clubs showed drops during the 11-12 season. Clubs like Chelsea, Liverpool, and Manchester United showed drops in their efficiency. In fact, Chelsea and Liverpool showed the particularly significant drops in efficiency. All of these clubs seem to have been affected by the Home-grown regulation due to the 
strain this regulation has imposed on the football clubs, when we consider the fact that drops in efficiency coincide with the implementation of the Home-grown regulation.

However, in case of Manchester City and Everton, it is very difficult to attribute the drops in their efficiency entirely to the Home-grown regulation. Manchester City had been largely run inefficiently before the implementation of the Home-grown regulation in the observed timeframes, which may have been due to the change in its ownership and the massive investment made to the club. In fact, the new owner of the club, City Football Group, renovated the stadium and changed the players and coaching staffs to completely transform the club, resulting in massive spending which, in part, led to the low efficiency score. Therefore, in this case, it is not clear how much impact the Home-grown regulation had compared to the massive investments that its holding company made. Because much of the investment on stadium and infrastructure has been made starting from 08-09 season, it can also be inferred that the impact of the Home-grown regulation may not have had impact on Manchester City like it did on other clubs. Everton went through similar changes after management promoted much of its squad from youth players, and those changes had an impact on its efficiency score.

In clubs' perspective, players' salaries, and transfer fees significantly affect the solvency and operating cost of the football club. As shown in the table 3 of this paper, personnel wage itself constitutes more than half of the operating cost, showing that overall increases in transfer fees and wages will significantly affect the clubs' running efficiency.

The Home-grown regulation has an impact on clubs in this particular manner. Requiring clubs to play and include certain number of English-bred players leads to the lack of supply of and the surge of demand for English players, making them extremely expensive and even unaffordable. This phenomenon has driven up the English players' transfer fees to unimaginable levels, leading to compromised efficiency on the clubs' part. In section 5, this paper seeks to further investigate this phenomenon and clarify this chain reaction of an event.

\section{Discussion}

Understanding the implications of the Home-grown regulation affects greatly on the efficiency management of the football clubs, and ultimately expansion of the league as the whole. This section will touch upon three discussion topics: First, we will discuss the inefficiency that the regulation imposes on the clubs as well as its efficacy in achieving their intended political purposes. Second, we will look into the difference in the regulation's effect on different clubs, which vary by situation. Lastly, we will consider whether the effects stemming from the implementation of the Home-grown regulation is a temporary shock or a lasting change.

\section{The Efficacy of Regulations}

The ultimate purpose of the Home-grown regulation is to utilize high standards and infrastructures of English Premier League to elevate the levels of English players. This, in turn, is hoped to lead to better 
results in the international tournaments for the England. In order to do so, the Home-grown regulation, and the new proposal must achieve following sets of criteria. First, they must allow younger English players to be endowed with more time in the field. More experience will lead to better performance, and it cannot be achieved without giving more field time to younger athletes. Second, English players, as a whole, must comprise bigger portion of the league. However, the Home-grown regulation and the new proposal fails to achieve both these requirements. Figure 5 shown above efficiency change before and after the Home-grown regulation enforcement

It has been well established throughout this paper that FA's Home-grown regulation and its proposal imposes financial burden causing massive inefficiency in affected football clubs. However, since these regulations contain political purposes, they must also be considered in a different light: the efficacy. According to various statistics, the regulation's efficacy is doubtful. It is evident from statistics that English players take lesser parts of the Premier League. According to Rhodes (2014), the percentage of English footballers in Premier League is consistently showing downward pattern despite all the regulations and breaks in place.

"A quick look at the transfer market reveals a rather striking downward trend in the percentage of homegrown talent in the PL. In fact, less than 1/3 of the league is actually comprised of footballers from England, it stands to reason that before the Premier League existed (pre-1992), the percentage of Englishmen was at least 70\% and probably higher (it was difficult to switch teams before 1995). It's not that the PL is filled with players from one foreign nationality; rather, the other $68 \%$ come from 65 different countries. The PL should be complemented on its wide diversity of its players" (p. 1). (Rhodes, 2014)

The Home-grown regulation has not shown any efficacy in nurturing the youth players in the Premier League. In fact, the harsh regulation has ironically led to detrimental effects in training young athletes. Statistics support that this regulation is not effective in promoting youth players to be introduced into the Premier League. English Premier League has given not only one of the lowest play time for youth players among all major football leagues in Europe, including Serie A and Bundesliga, but also one of the lowest number of contracts for youth players. For example, according to Tayloer (2008), In the 2006-7 season, 498 players started Premier League games. Of these, only 191 were English - just 38\%. Statistics suggest that even after the Home-grown regulation in place, football clubs in England still prefers to sign expensive ready-made players with much more experience. The league's tendency to prefer such players deters the growth of young English athletes, thus rendering such regulations inefficient or virtually useless.

It can be seen that England has the highest number of international and expatriate's percentage along with minimal percentage of club-trained players next to Italy. With the lowest percentage of English footballers in the Premier League, it is not impossible to understand the FA's proposal to tighten the Home-grown regulation. Even after the major clauses have been adopted in the 2010-2011 season, there has been a consistent trend of downward drop in the percentage of not only youth players in the field, but also in English players as a whole. 
The efficacy of the Home-grown regulation has thus proved to be minimal (Danziel et al, 2013). However, the FA insists on strengthening regulations for the similar reasons that failed to be achieved by the previous regulations (The FA, 2016). According to proposal, each football club must include 12 or more English or Welsh players in the designated 25 people roster. This would impose heightened demand on English players, making it more difficult for clubs to find players with both nationality and decent performance. Moreover, the Home-grown regulation can be interpreted as protectionism for national players. Considering the fact that much of the popularity derives from the various parts of the globe, it is a very perilous move to put in discriminative clause in the regulation that might upset the global fans of EPL. It seems highly recommendable for the FA to reconsider its clauses in the regulation.

\section{Consideration for initial conditions}

The football clubs will face the same or similar costs in fulfilling the mandated regulation. It is no secret that some of the clubs such as Arsenal and Manchester United have superior youth academy system to supply their first teams with better and younger English players. However, many other clubs do not have the same advantage. For the former clubs, it will be much less costly to fulfill the regulation, as they can supply players with much more ease. However, for the latter, the story is not the same.

The DEA in this paper substantiates this claim. Some of the clubs are relatively less impacted by the augmented the Home-grown regulation, whereas other clubs are heavily impacted. This is shown in the DEA scores. The clubs which rank among lower $50 \%$ of efficiency scores tend to stay in the lower category even after the implementation, showing their inability to cope with huge financial burden imposed by the regulation. The clubs that tend to cope well and stay in the upper $50 \%$ are the clubs such as Manchester United, and Arsenal. This difference is derived from difference in the youth academy among clubs. A few clubs such as Manchester United have maintained a high-quality youth academy which has helped them in adapting to the Home-grown regulation. However, other clubs which did not have or had lesser ability in raising younger athletes, such as Fulham and Aston Villa, faced higher costs in adapting, for they previously retained a team with foreigners consisting much of the roster sheet. Following chart summarizes the changes in efficiency score before and after the home-grown clause was put in place.

The home-grown clause has affected the efficiency of football clubs differently, and in the case of Manchester United, the club benefited from the strengthened clause for it had a strong youth academy including the U-21 (Under the age of 21) teams. In fact, Manchester United was able to supply homegrown players without incurring much cost, whereas other clubs had much burden. As shown above, Aston Villa, Fulham, and Sunderland stayed as lower $50 \%$ in efficiency, as it used the policy to sign cheaper players from abroad to consist its team before the regulation. Many of these clubs have low percentage of English players, and it was pushed to sign English players to meet the regulation's requirements. What must be noted here is that the Home-grown regulation affects each team to a different degree, thereby creating artificial discrepancies that unfairly discriminate teams financially. 
Therefore, aside from the obvious financial impact that affects all teams, this regulation is unfair in its influence.

\section{Consideration of temporary shock}

The DEA results show a tendency of concentrated drop over the 2011-2012 season, while after the initial concentrated shock, clubs show a little recovery but never fully recovers. Therefore, it is important to investigate whether this shock is temporary or has long-term effects on the clubs. In order to look into this matter, further observation is needed for a longer timeframe. At this point in time, due to the lack of data starting form 14-15 season, it is difficult to make any further observations. However, as the three years after the implementation of the Home-grown regulation have not been enough for clubs to fully recover, it can be said that this regulation has lasting influence in a medium to long term range.

Nonetheless, regardless of how long the regulation's effect lasts, there is no doubt that this regulation imposes impact that is significant enough to financially and operationally sway the clubs. In fact, in the 2010-11 season, the clubs had already prepared for years for the home-grown clause and so were able to minimize the impact. However, starting from the next 2011-12 season when clubs had to make amends to their roster, their operational and financial efficiency plummeted with minimal signs of recovery. It is clear that this regulation imposes burden on football clubs for the price of achieving a political goal which, as discussed earlier, is showing infinitesimal progress.

With the FA recently proposing to toughen these regulations starting from 16-17 season, where clubs would be required to increase the number of English player to 12 per 25 roster with stricter imposition on home-grown status, there is no doubt that this will create a massive shock that would be incomparable to the previous shock when the regulation was first implemented. Therefore, the newly revised the Homegrown regulation must be receded for further consideration.

\section{Lack of English Players in major leagues?}

While English National Team's lack of performance hints the inefficacy of the FA's Home-grown regulation, others can argue that English Team's sagging performance is the result of the lack of English players playing in major football leagues abroad. However, this assertion is not entirely true. Poli (2009) asserts his claim in following manner.

In total, in 2006/07 there were 28 English international footballers that played for the top five clubs in the major five leagues in European football. This figure appears to be high enough to form a competitive national squad ( $p .43)$.

In fact, if we take into account the number of international players in the five major European leagues, the result becomes clearer. According to Poli (2009), Table 11 shows the countries with the most international players in the five major European leagues for the $06 / 07$ season. 
In fact, this table shows that England has 67 players who played in the five major European league in 06/07 season. This is more than "60 German Internationals and 59 French internationals" (p. 42) (Poli 2009). If we take into account the fact that Germany was in the third place and France was the runner-up in the 2006 World Cup, the lagging performance of English international football team is not explained by the lack of English players who play in foreign leagues. Rather, foreign players help the improvement of the domestic league and players. According to Berlinschi et al (2012), "the effect of migration on national team performance is positive and that it increases with the difference in the quality of training between foreign and home clubs" (p. 23).

In addition, if we consider the average number of league matches played by international players by nationality, it becomes obvious that lack of English players in foreign leagues is not the main factor in lacking performance. Poli (2009) proves further point by showing Table 12 - Average number of league matches played by international players by nationality for season $06 / 07$.

Here we can also see that English international footballers do not lack matches nor the playing time in the foreign leagues. In fact, Poli (2009) analyzes in following manner:

It shows that the English international players employed by the top clubs in Europe play on average a little less than Spanish, French or Italian players, although the differences are unlikely to lead to the conclusion that their competitiveness is affected. By way of comparison, although the German full international players at the top clubs in Europe played less than the English counterparts, this did not prevent Germany from qualifying for the final phase of Euro 2008 (p. 44).

Rather, the problem lies elsewhere. From the youth academy point, English players lack technical ability and mentality while overly focusing on physical aspect and speed. According to Elliott and Weedon (2010), coaches at English football club youth academy describes the critical difference between foreign players and English players as following:

[Foreign players] are far more technically oriented... Technique is so important, it's the great English drawback. Physically we're good, tactically we're okay, but technically we're poor. The Dutch and the Italians totally leave us standing. The [foreign] boys we've got, their technique is really really good, and there's the challenge for the English boys, they've learnt that they have to work on their technique ( $p .71)$.

In fact, due to the feet-exchange between foreign players and English players in youth academy, Elliott and Weedon argues that inviting foreign players into the English football has helped English players greatly in the youth level (2010). English players not only reported improvement in skill, but also improvement in the mentality (Elliott and Weedon 2009). Therefore, it should be argued that there are plenty of English players in the foreign major football leagues and that lack of English international footballers is not the reason for sagging performance. As Berlinschi et al (2012), Poli (2009), and Elliott and Weedon (2009) asserts, there is a positive correlation between foreign players in the league and the national team's performance. Therefore, it should be considered that English players lack the 
development of crucial technical skills, making it ever more important to accept the foreign players who have superior skill levels.

\section{Conclusions}

This study uses SORM-DEA method to observe the changes in the efficiency of English football clubs chronologically to evaluate the effect of the Home-grown regulation. The timeframe was divided into two different periods: 3 years before the 2010-2011 season and 3 years after the 2010-2011 season, taking into account the fact that the 2010-2011 season is the season when the main clauses of the home-grown rules in EPL were adopted. Dividing the timeframe into two periods allowed us to see the impact that this regulation had on both clubs' operation and finances. The DEA method used in this study utilizes the previously reviewed literature as guidelines for setting the input factors, output factors, and the DMUs in evaluating the efficiency of football clubs in many different leagues such as La Liga, Bundesliga, and Ligue 1.

According to the DEA results, the efficiency of the clubs, although varied depending on initial situations, showed a downward pattern after the implementation of the Home-grown regulation clause. This trend tended to last for a few years, during which the efficiency score of the club significantly dropped. Moreover, the Home-grown regulation with its political motivations, did not even show minimum efficacy for its validation. In fact, according to various research, the regulation worsened the environment for the English football.

However, the FA is pushing to strengthen the Home-grown regulation by strongly asserting its political motivations and heavily relying on current status quo. The present study contributes to the argument that it is highly undesirable to strengthen or even retain the Home-grown regulation. The current measures proposed by the FA will work to massively burden football clubs, jeopardizing the football clubs both financially and operationally.

\section{References}

Amenta, C., Ballor, C., Di Betta, P. (2012). The role of financial and managerial variables on the policy towards home-grown players in English soccer. International Business Research, 5(11), 28-34. Retrieved from https://papers.ssrn.com/

Asmild, M., \& Pastor, J. T. (2010). Slack free MEA and RDM with comprehensive efficiency measures. Omega, 38(6), 475-483. doi: 10.1016/j.omega.2009.12.004

Banker, R. D., Charnes, A., and Cooper, W, W. (1984). Some models for estimating technical and scale inefficiencies in data envelopment analysis. Management science,30(9), 1078-92. doi:

$10.1287 / \mathrm{mnsc} .30 .9 .1078$ 
Barros, C. (2003). Incentive regulation and efficiency in sport organisational training activities. Sport Management Review,6(1), 33-52. doi: 10.1016/S1441-3523(03)70052-7

Barros, C., Leach, S. (2006a). Performance evaluation of the English Premier Football League with data envelopment analysis. Applied Economics,38, 1449-58. doi: 1080/00036840500396574

Barros, C., Leach, S. (2006b). Analyzing the performance of the English FA Premier League with an econometric frontier model. Journal of Sports Economics, 7(4), 391-407. doi:

$10.1177 / 1527002505276715$

Barros, C., Santos, A. (2003). Productivity in sports organisational training activities: a DEA study. European Sport Management Quarterly3(1), 46-65. doi: 1080/16184740308721939

Berlinschi, R., Schokkaert, J., Swinnen, J. (2013). When drains and gains coincide: Migration and international football performance. Labour Economics,21, 1-14. doi: 1016/j.labeco.2012.12.006

(2015, February 10). Premier League in record £5.14bn TV rights deal. Retrieved June 12, 2017, from http://www.bbc.com/news/business-31379128

Boussofiane, A., Dyson, R. G., \& Thanassoulis, E. (1991). Applied data envelopment analysis. European Journal of Operational Research, 52(1), 1-15. doi: 10.1016/0377-2217(91)90331-0

Bullough, S., Mills, A. (2014). Give us a game: Evaluating the opportunities that exist for English footballers to play in the English Premier League. International Journal of Sports Science \& Coaching, 9(4), 637-50. doi: 10.1260/1747-9541.9.4.637

Charles, V., Färe, R., \& Grosskopf, S. (2016). A translation invariant pure DEA model. European Journal of Operational Research, 249(1), 390-392. doi: 10.1016/j.ejor.2015.09.037

Charnes, A., William, W. C. and Rhodes, E. (1978). Measuring the efficiency of decision making units, European Journal of Operational Research,2(6), 429-44. doi: 10.1016/0377-2217(78)90138-8

Cheng, G., Zervopoulos, P., \& Qian, Z. (2013). A variant of radial measure capable of dealing with negative inputs and outputs in data envelopment analysis. European Journal of Operational Research, 225(1), 100-105. doi: 10.1016/j.ejor.2012.09.031

CIES Football Observatory Big-5 Data. (2015). Retrieved from http://www.footballobservatory.com/Indicators.

Cooper, W. W., Seiford, L. M., \& Tone, K. (2004). Introduction to DEA-Solver-Pro (Professional Version 4.1). DEA-Solver-Pro Newsletter, 8(5).

Dalziel, M., Downward, P., Parrish, R., Pearson, G., Semens, A. (2013). Study on the Assessment of UEFA's 'Home-grown Player Rule'. The University of Liverpool and Edge Hill University, 1-38. Retrieved from 
Emrouznejad, A., Anouze, A. L., \& Thanassoulis, E. (2010). A semi-oriented radial measure for measuring the efficiency of decision making units with negative data, using DEA. European Journal of Operational Research, 200(1), 297-304. doi: 10.1016/j.ejor.2009.01.001

Elliott, R., and Weedon, G. (2010). Foreign players in the English Premier Academy League:'Feet-drain'or 'feet-exchange'?. International review for the sociology of sport, 46(1), 61-75. doi:

$10.1177 / 1012690210378268$

Espita-Escuer, M., Garcia-Cebrian, L. (2010) Measurement of the Efficiency of Football Teams in the Champions League. Managerial and Decision Economics,31, 373-86. doi: 10.1002/mde.1491

The FA. (2015, March 23). FA Chairman's update on England Commission. The Football Association. Retrieved from http://www.thefa.com/

Haas, D. J. (2003) Productive Efficiency of English Football Teams-A Data Envelopment Analysis Approach. Managerial and Decision Economics,24(5), 403-410. doi: 0.1002/mde.I 105

Henderson, T. (2011). The English Premier League's Home-grown Player Rule Under the Law of the European Union. Brooklyn Journal of International Law,37, 259-90. Retrieved from http://heinonline.org/

García-Sánchez, I. M. (2007). Efficiency and effectiveness of Spanish football teams: a three-stage-DEA approach. Central European Journal of Operations Research,15(1), 21-45. doi: 10.1007/s10100-006-00174

Gardiner, S., Welch, R. (2011). Nationality and protectionism in football: why are FIFA's '6+ 5 rule'and UEFA's 'home-grown player rule'on the agenda?. Soccer \& Society, 12(6), 774-787. doi:

$10.1080 / 14660970.2011 .609679$

Gordon, T. (2008). Meltdown: The nationality of Premier League players and the future of English football. Birkbeck Sport Business Centre Research Paper Series,51. Retreived from http://www.sportbusinesscentre.com/

Guzmán, I. (2006). Measuring Efficiency and Sustainable Growth in Spanish Football Teams. European Sport Management Quarterly,6(3), 267-287. doi: 10.1080/16184740601095040

Guzmán, l., Morrow, S. (2007). Measuring efficiency and productivity in professional football teams: evidence from the English Premier League. Central European Journal of Operations Research, 15(4), 309328. doi: 10.1007/s10100-007-0034-y

James, S. (2006, August 04). Why clubs may risk millions for riches. The Guardian. Retrieved from https://www.theguardian.com/football/2006/aug/05/championship200607 
Jewell, A. (2014, June 25). Premier League: PFA boss Gordon Taylor wants home-grown quota. BBC. Retrieved from http://www.bbc.com/

Miller, A. (2011, October 29). Exclusive: Official figures show top-flight wages are now FIVE times more than in Championship. Daily Mail. Retrieved June 18, 2017, from

http://www.dailymail.co.uk/sport/football/article-2055140/Premier-League-wages-FIVE-timesChampionship.html

Morrow, S. (2003). The people's game?: football, finance and society. Springer.

Nesti, M., Sulley, C. (2014). Youth Development in football: Lessons from the world's best academies. Routledge.

Nyhan, R. C., \& Martin, L. L. (1999). Comparative performance measurement: a primer on data envelopment analysis. Public Productivity \& Management Review, 348-364. Retrieved from http://www.jstor.org/

Park, C. J., (2015, June 21). English Premier League Transfer Market Keyword: The Home-grown regulation. Chosun I/bo. Retrieved from http://news.chosun.com/

Pastor, J. T., \& Ruiz, J. L. (2007). Variables with negative values in DEA. In Modeling data irregularities and structural complexities in data envelopment analysis (pp. 63-84). Springer US. Retrieved from http://link.springer.com/

Poli, R. (2009). Labour market migration to the five major leagues in European football: the impact on national team selection. Labour Market Migration in European Football: Key Issues and Challenges, 3250. Retrieved from http://www.sportbusinesscentre.com/

The Premier League. (2015). Premier League Rankings. The Barclays Premier League Retreived from http://www.premierleague.com/

Rhodes, P. (2014, June 02). Swallowing the Bitter Pill: England, the Premier League and the World Cup. [Web log post]. Retreived from http://www.statisticsviews.com/

Quirk, J., and El-Hodiri, M. (1974). The economic theory of professional sport league. Government and Sport Business (Ed.) R. Noll, Brookings Institution, 33-80.

Skysports. (2015a, March 25). FA home-grown rules: Man City, Arsenal, Chelsea would lose players.Skysports. Retrieved from http://www.skysports.com/

Skysports. (2015b, March 24). No longer home-grown XI: Stars who would lose status under FA plan.Skysports. Retrieved from http://www.skysports.com/

Szymanski, S., Kuypers, T. (1999). Winners and losers. London: Viking. 
UEFA Member Associations Rankings. (2015). Retreieved from http://www.uefa.com/

\section{Tables}

Table 1. Summary of notable UEFA regulations

\begin{tabular}{|lll|}
\hline Regulation & Governing Body & Major Provisions (Current) \\
\hline $\begin{array}{l}\text { Home- } \\
\text { Grown }\end{array}$ & Footall Association & $\begin{array}{l}\text { Requires clubs to include eight home-grown players out of a } \\
\text { squad of } 25\end{array}$ \\
$\begin{array}{l}\text { Financial } \\
\text { Fair Play }\end{array}$ & $\begin{array}{l}\text { Union of European } \\
\text { Football Association }\end{array}$ & $\begin{array}{l}\text { Requires clubs to balance their spending with their revenues } \\
\text { and restricts clubs from accumulating debt }\end{array}$ \\
\hline
\end{tabular}

\section{Table 2. Summary of literature Review}




\begin{tabular}{|c|c|c|c|c|}
\hline $\begin{array}{l}\text { Related } \\
\text { Study }\end{array}$ & Inputs & Outputs & Model & DMUs \\
\hline \multirow{3}{*}{$\begin{array}{l}\text { Guzmán } \\
\text { and } \\
\text { Morrow } \\
(2007)\end{array}$} & $\begin{array}{l}\text { 1. Staff cost (player's wage, } \\
\text { managers, coaching staff, } \\
\text { other staffs) }\end{array}$ & $\begin{array}{l}\text { 1. Points won in } \\
\text { the EPL }\end{array}$ & \multirow{3}{*}{$\begin{array}{l}\text { DEA-Input } \\
\text { Oriented } \\
\text { / Malmquist } \\
\text { Productivity } \\
\text { Index }\end{array}$} & \multirow[t]{3}{*}{$\begin{array}{l}60 \text { DMUs of } \\
\text { EPL }(98 / 99- \\
02 / 03)\end{array}$} \\
\hline & 2. Director's remuneration & \multirow{2}{*}{$\begin{array}{l}\text { 2. Club's financial } \\
\text { success (turnover) }\end{array}$} & & \\
\hline & $\begin{array}{l}\text { 3. general other operating } \\
\text { expenses of club }\end{array}$ & & & \\
\hline \multirow[t]{2}{*}{$\begin{array}{l}\text { Guzmán } \\
(2006)\end{array}$} & $\begin{array}{l}\text { 1. staff cost (including all } \\
\text { those employed }\end{array}$ & \multirow{2}{*}{$\begin{array}{l}\text { 1. turnover (gate } \\
\text { takings, radio, tv } \\
\text { broadcasting) }\end{array}$} & \multirow{2}{*}{$\begin{array}{l}\text { DEA Models, } \\
\text { Malmquist } \\
\text { Productivity } \\
\text { Index }\end{array}$} & \multirow{2}{*}{$\begin{array}{l}14 \text { La liga } \\
\text { clubs for } 3 \\
\text { years }(00-03)\end{array}$} \\
\hline & $\begin{array}{l}\text { 2. general expenses of } \\
\text { the club }\end{array}$ & & & \\
\hline \multirow{4}{*}{$\begin{array}{l}\text { Barros } \\
\text { and Leach } \\
(2006 a)\end{array}$} & 1. number of players, & $\begin{array}{l}\text { 1. Points obtained } \\
\text { in season }\end{array}$ & \multirow{4}{*}{$\begin{array}{l}\text { DEA-CCR/BCC } \\
\text { Model Input- } \\
\text { Oriented }\end{array}$} & \multirow{4}{*}{$\begin{array}{l}115 \text { DMUs } \\
\text { from EPL } \\
\text { Club (97-03) }\end{array}$} \\
\hline & 2.wages, & 2. attendance & & \\
\hline & 3. net assets & \multirow[t]{2}{*}{ 3. turnover } & & \\
\hline & $\begin{array}{l}\text { 4. stadium facilities } \\
\text { expenditure }\end{array}$ & & & \\
\hline \multirow[t]{3}{*}{$\begin{array}{l}\text { Haas } \\
(2003)\end{array}$} & $\begin{array}{l}\text { 1.total wages and salaries - } \\
\text { amount to head coach }\end{array}$ & \multirow[t]{2}{*}{$\begin{array}{l}\text { 1. points awarded } \\
\text { in EPL }\end{array}$} & \multirow[t]{3}{*}{ DEA CCR/BCC } & \multirow{3}{*}{$\begin{array}{l}20 \mathrm{EPL} \\
\text { teams in } \\
2000 / 2001\end{array}$} \\
\hline & 2. Head coach salary & & & \\
\hline & $\begin{array}{l}\text { 3. population of the club's } \\
\text { hometown (non-discre } \\
\text { variable) }\end{array}$ & $\begin{array}{l}\text { 2. Season total } \\
\text { Revenue }\end{array}$ & & \\
\hline \multirow[t]{4}{*}{$\begin{array}{l}\text { Espita- } \\
\text { Escuer } \\
\text { (2010) }\end{array}$} & $\begin{array}{l}\text { 1. number of players used } \\
\text { throughout the length of } \\
\text { the season }\end{array}$ & 1. Results & \multirow{4}{*}{$\begin{array}{l}\text { Traditional DEA } \\
\text { with Version } \\
\text { endorsed } \\
\text { by Anderson and } \\
\text { Petersen (1993) }\end{array}$} & \multirow{4}{*}{$\begin{array}{l}\text { Teams } \\
\text { Played in } \\
\text { UEFA } \\
\text { Champions } \\
\text { League } \\
\text { from } 03 / 04- \\
06 / 07\end{array}$} \\
\hline & $\begin{array}{l}\text { 2. number of attacking } \\
\text { moves }\end{array}$ & \multirow[t]{3}{*}{$\begin{array}{l}\text { 2. On-field } \\
\text { Performances }\end{array}$} & & \\
\hline & $\begin{array}{l}\text { 3. the number of minutes of } \\
\text { ball possession }\end{array}$ & & & \\
\hline & $\begin{array}{l}\text { 4. number of shots and } \\
\text { headers }\end{array}$ & & & \\
\hline
\end{tabular}

Table 3. Statistical result of the pairwise comparison model 


\begin{tabular}{|c|c|c|c|c|c|}
\hline Sample 1-Sample 2 & Test Statistic & SD. error & SD. test statistic & Sig. & Adj. Sig. \\
\hline $2^{\text {nd }}$ Model- $3^{\text {rd }}$ Model & -78.664 & 13.652 & -5.762 & .000 & .000 \\
\hline $2^{\text {nd }}$ Model -Original & 119.550 & 13.652 & 8.757 & .000 & .000 \\
\hline $2^{\text {nd }}$ Model $-1^{\text {st }}$ Model & 120.100 & 13.652 & 8.797 & .000 & .000 \\
\hline $3^{\text {rd }}$ Model - Original & 40.886 & 13.652 & 2.995 & .003 & .016 \\
\hline $3^{\text {rd }}$ Model $-1^{\text {st }}$ Model & 41.436 & 13.652 & 3.035 & .002 & .014 \\
\hline Original $-1^{\text {st }}$ Model & -.550 & 13.652 & -.040 & .968 & 1.000 \\
\hline
\end{tabular}

Each row tests the null hypothesis that the Sample 1 and Sample 2 distributions are the same. Asymptotic significances (2-sided tests) are displayed. The significance level is .05

Table 4. Descriptive statistics (Units: Million GBP) 


\begin{tabular}{|c|c|c|c|c|c|c|}
\hline & & Net Asset & Operating Cost & Turnover & Operating Profit & Points Earned \\
\hline \multirow[t]{5}{*}{$2007-2008$} & Mean & 74.30 & 133.53 & 109.33 & -9.63 & 63.20 \\
\hline & Median & 36.37 & 104.10 & 78.97 & -1.65 & 62.50 \\
\hline & SD & 137.64 & 82.61 & 78.95 & 25.75 & 19.15 \\
\hline & Max & 432.14 & 274.14 & 256.24 & 26.73 & 87.00 \\
\hline & Min & -59.00 & 4.42 & 21.02 & -64.54 & 36.00 \\
\hline \multirow[t]{5}{*}{ 2008-2009 } & Mean & 105.48 & 158.07 & 145.87 & -7.74 & 64.60 \\
\hline & Median & 58.51 & 146.68 & 100.02 & -5.22 & 62.50 \\
\hline & SD & 15.41 & 84.12 & 92.36 & 4.95 & 17.82 \\
\hline & Max & 455.51 & 274.83 & 313.30 & 48.19 & 9.00 \\
\hline & Min & -3.88 & 61.55 & 63.14 & -92.56 & 36.00 \\
\hline \multirow[t]{5}{*}{ 2009-2010 } & Mean & 167.56 & 18.51 & 16.44 & -25.08 & 66.10 \\
\hline & Median & 69.50 & 163.39 & 122.43 & -3.34 & 65.50 \\
\hline & SD & 239.50 & 99.67 & 105.25 & 49.89 & 14.07 \\
\hline & Max & 777.24 & 344.31 & 382.00 & 35.55 & 86.00 \\
\hline & Min & -29.77 & 69.94 & 65.28 & -121.30 & 44.00 \\
\hline \multirow[t]{5}{*}{$2010-2011$} & Mean & 252.26 & 171.71 & 164.33 & -3.21 & 6.80 \\
\hline & Median & 76.53 & 202.21 & 158.34 & -5.91 & 6.00 \\
\hline & SD & 495.78 & 13.78 & 86.05 & 65.91 & 11.44 \\
\hline & Max & $1,635.02$ & 348.12 & 331.44 & 29.72 & 8.00 \\
\hline & Min & -35.19 & -99.17 & 76.41 & -197.00 & 47.00 \\
\hline \multirow[t]{5}{*}{$2011-2012$} & Mean & 259.28 & 189.48 & 166.54 & -16.17 & 62.40 \\
\hline & Median & 61.74 & 17.90 & 156.58 & -8.21 & 6.00 \\
\hline & SD & 476.44 & 102.63 & 91.97 & 17.69 & 17.24 \\
\hline & Max & $1,561.68$ & 348.03 & 32.32 & 1.38 & 89.00 \\
\hline & Min & -44.29 & 71.14 & 63.85 & -5.63 & 38.00 \\
\hline \multirow[t]{3}{*}{$2012-2013$} & Mean & 275.50 & 201.98 & 183.88 & -27.91 & 63.40 \\
\hline & Median & 77.76 & 188.67 & 176.75 & -19.24 & 67.50 \\
\hline & SD & 488.55 & 115.68 & 106.18 & 33.00 & 17.28 \\
\hline
\end{tabular}




\begin{tabular}{|cllllll|}
\hline \multirow{2}{*}{ 2013-2014 } & Max & $1,587.01$ & 369.35 & 363.19 & 4.00 & 89.00 \\
\cline { 2 - 4 } & Min & -44.59 & 65.01 & 72.03 & -104.09 & 39.00 \\
\cline { 2 - 4 } & Mean & 318.95 & 219.19 & 222.75 & 3.94 & 64.40 \\
\cline { 2 - 5 } & 12.99 & 211.26 & 218.09 & 5.49 & 7.50 \\
\hline SD & 524.34 & 119.50 & 126.00 & 63.69 & 2.81 \\
\hline Max & $1,699.82$ & 371.56 & 433.16 & 19.67 & 86.00 \\
\hline
\end{tabular}

Table 5. Efficiency Score after the Homegrown regulation enforcement (Original Model)

\begin{tabular}{|llllllll|}
\hline DMU & $(07-08)$ & $(08-09)$ & $(09-10)$ & $(10-11)$ & $(11-12)$ & $(12-13)$ & $(13-14)$ \\
\hline Arsenal & 1.000 & 1.000 & 1.000 & .6281 & .4070 & .4942 & .5188 \\
\hline Aston Villa & 1.000 & .3239 & .2885 & .3577 & .3928 & .5604 & .3758 \\
\hline Chelsea & 1.000 & .8238 & 1.000 & 1.000 & .0779 & .5982 & 1.000 \\
\hline Everton & 1.000 & 1.000 & .7745 & 1.000 & 1.000 & 1.000 & 1.000 \\
\hline Fulham & 1.000 & 1.000 & 1.000 & 1.000 & .3271 & .5959 & .1733 \\
\hline Liverpool & .7768 & 1.000 & .2203 & .5770 & .6194 & .9009 & 1.000 \\
\hline Manchester City & .7346 & .7010 & .5096 & .5529 & 1.000 & .6573 & 1.000 \\
\hline Manchester United & .7180 & 1.000 & .8544 & 1.000 & .8285 & 1.000 & 1.000 \\
\hline Sunderland & 1.000 & .6544 & .6737 & .7400 & .6510 & .6279 & .6808 \\
\hline Tottenham Hotspur & 1.000 & 1.000 & .8947 & .0353 & .3573 & .2717 & 1.000 \\
\hline
\end{tabular}

Table 6. Efficiency Score after the Homegrown regulation enforcement (Revised Model) 


\begin{tabular}{|c|c|c|c|c|c|c|c|c|}
\hline DMU & Model & $\begin{array}{l}(07- \\
08)\end{array}$ & $\begin{array}{l}(08- \\
09)\end{array}$ & $\begin{array}{l}(09- \\
10)\end{array}$ & $\begin{array}{l}(10- \\
11)\end{array}$ & $\begin{array}{l}(11- \\
12)\end{array}$ & $\begin{array}{l}(12- \\
13)\end{array}$ & $\begin{array}{l}(13- \\
14)\end{array}$ \\
\hline \multirow[t]{3}{*}{ Arsenal } & $\begin{array}{l}\text { Model } \\
(1)\end{array}$ & 0.9521 & 0.8207 & 0.8492 & 0.7700 & 0.7900 & 0.8226 & 0.8899 \\
\hline & $\begin{array}{l}\text { Model } \\
\text { (2) }\end{array}$ & 0.2722 & 0.3320 & 0.2506 & 0.1562 & 0.0887 & 0.1293 & 0.0618 \\
\hline & $\begin{array}{l}\text { Model } \\
\text { (3) }\end{array}$ & 0.7912 & 0.9438 & 1.0000 & 0.8280 & 0.7498 & 0.7872 & 0.8722 \\
\hline \multirow[t]{3}{*}{ Aston Villa } & $\begin{array}{l}\text { Model } \\
\text { (1) }\end{array}$ & 0.8469 & 0.8447 & 0.8580 & 0.6263 & 0.5097 & 0.5555 & 0.5172 \\
\hline & $\begin{array}{l}\text { Model } \\
\text { (2) }\end{array}$ & 0.0238 & 0.0516 & 0.0613 & 0.0974 & 0.1065 & 0.2192 & 0.0805 \\
\hline & $\begin{array}{l}\text { Model } \\
\text { (3) }\end{array}$ & 0.2642 & 0.4198 & 0.4088 & 0.4664 & 0.3337 & 0.4350 & 0.4059 \\
\hline \multirow[t]{3}{*}{ Chelsea } & $\begin{array}{l}\text { Model } \\
\text { (1) }\end{array}$ & 1.0000 & 0.9422 & 0.9837 & 0.8181 & 0.7241 & 0.8454 & 0.9178 \\
\hline & $\begin{array}{l}\text { Model } \\
\text { (2) }\end{array}$ & 1.0000 & 0.1995 & 0.2894 & 0.3227 & 0.0095 & 0.1937 & 1.0000 \\
\hline & $\begin{array}{l}\text { Model } \\
\text { (3) }\end{array}$ & 1.0000 & 0.6193 & 0.6308 & 0.7218 & 0.7185 & 0.7008 & 0.8284 \\
\hline \multirow[t]{3}{*}{ Everton } & $\begin{array}{l}\text { Model } \\
\text { (1) }\end{array}$ & 0.8846 & 0.8617 & 0.8274 & 1.0000 & 0.7823 & 0.8732 & 0.9271 \\
\hline & $\begin{array}{l}\text { Model } \\
\text { (2) }\end{array}$ & 0.0013 & 0.2485 & 0.1713 & 1.0000 & 1.0000 & 1.0000 & 1.0000 \\
\hline & $\begin{array}{l}\text { Model } \\
\text { (3) }\end{array}$ & 0.4117 & 0.4300 & 0.4155 & 1.0000 & 0.6697 & 0.4839 & 0.5913 \\
\hline \multirow[t]{3}{*}{ Fulham } & $\begin{array}{l}\text { Model } \\
\text { (1) }\end{array}$ & 0.4848 & 0.7053 & 0.6182 & 0.6542 & 0.6873 & 0.5646 & 0.4150 \\
\hline & $\begin{array}{l}\text { Model } \\
\text { (2) }\end{array}$ & 0.2413 & 0.1861 & 0.2122 & 0.0869 & 0.0260 & 0.1766 & 0.0059 \\
\hline & $\begin{array}{l}\text { Model } \\
\text { (3) }\end{array}$ & 0.2775 & 0.3300 & 0.4128 & 0.4067 & 0.4121 & 0.3757 & 0.4648 \\
\hline \multirow[t]{3}{*}{ Liverpool } & $\begin{array}{l}\text { Model } \\
\text { (1) }\end{array}$ & 0.9102 & 1.0000 & 0.7367 & 0.6720 & 0.6055 & 0.7328 & 1.0000 \\
\hline & $\begin{array}{l}\text { Model } \\
\text { (2) }\end{array}$ & 0.2237 & 0.0752 & 0.0631 & 0.3250 & 0.3464 & 0.5077 & 1.0000 \\
\hline & $\begin{array}{l}\text { Model } \\
\text { (3) }\end{array}$ & 0.6968 & 0.7487 & 0.7498 & 0.6327 & 0.6855 & 0.8566 & 1.0000 \\
\hline Manchester City & Model & 0.7228 & 0.6267 & 0.7565 & 0.8024 & 1.0000 & 0.8682 & 0.9556 \\
\hline
\end{tabular}


(1)

$\begin{array}{llllllll}\begin{array}{l}\text { Model } \\ (2)\end{array} & 0.3174 & 0.4689 & 0.3107 & 0.3627 & 0.1853 & 0.2610 & 0.0789\end{array}$

$\begin{array}{llllllll}\begin{array}{l}\text { Model } \\ (3)\end{array} & 0.4243 & 0.3867 & 0.3892 & 0.4004 & 0.6011 & 0.6978 & 0.8812\end{array}$

Manchester

United

$\begin{array}{llllllll}\text { Model } & 0.9725 & 1.0000 & 0.9444 & 0.8889 & 0.9889 & 0.9889 & 0.7111\end{array}$

\begin{tabular}{|lllllllll|}
\hline & $\begin{array}{l}\text { Model } \\
(2)\end{array}$ & 0.1114 & 0.3096 & 0.2519 & 0.1897 & 0.0271 & 0.0171 & 0.2161 \\
\cline { 2 - 6 } & $\begin{array}{l}\text { Model } \\
(3)\end{array}$ & 0.7831 & 0.8267 & 0.8277 & 0.9245 & 0.8688 & 0.9444 & 1.0000 \\
\hline & $\begin{array}{l}\text { Model } \\
(1)\end{array}$ & 0.5276 & 0.4688 & 0.5665 & 0.5922 & 0.5725 & 0.5035 & 0.4718 \\
& $\begin{array}{l}\text { Model } \\
(2)\end{array}$ & 0.0444 & 0.2494 & 0.2708 & 0.2624 & 0.2734 & 0.2234 & 0.2120 \\
\hline $\begin{array}{l}\text { Tottenham } \\
\text { Hotspur }\end{array}$ & $\begin{array}{l}\text { Model } \\
(3)\end{array}$ & 0.3313 & 0.3160 & 0.3120 & 0.3638 & 0.3694 & 0.3422 & 0.4574 \\
& $\begin{array}{l}\text { Model } \\
(1)\end{array}$ & 0.5681 & 0.6221 & 0.8490 & 0.7194 & 0.8149 & 0.8416 & 0.7898 \\
\hline $\begin{array}{l}\text { Model } \\
(2)\end{array}$ & 0.1406 & 0.4012 & 0.3067 & 0.0059 & 0.0924 & 0.0607 & 0.7449 \\
\hline $\begin{array}{l}\text { Model } \\
(3)\end{array}$ & 0.5226 & 0.4954 & 0.5166 & 0.6470 & 0.5928 & 0.5955 & 0.6320 \\
\hline
\end{tabular}

Table 7. Comparative statistics on usage of home-grown players in major football leagues

\begin{tabular}{|lllllll|}
\hline & France & Germany & Spain & Italy & England & All \\
\hline Average Age & 26.28 & 25.98 & 26.67 & $\mathbf{2 7 . 5 3}$ & 27.01 & 26.72 \\
\hline Average Height & 181.3 & $\mathbf{1 8 3 . 2 9}$ & 18.68 & 182.61 & 182.95 & 182.12 \\
\hline \% club-trained & 19.28 & 14.99 & 18.71 & $\mathbf{8 . 5 2}$ & 1.16 & 14.3 \\
\hline \% internationals & 43.6 & 61.43 & 38.9 & 6.52 & $\mathbf{7 6 . 2 7}$ & 55.87 \\
\hline \% expatriates & 3.69 & 44.9 & 4.78 & 56.65 & $\mathbf{5 7 . 5 7}$ & 46.17 \\
\hline Average Stay & 2.54 & $\mathbf{2 . 8 5}$ & 2.66 & 2.38 & 2.82 & 2.64 \\
\hline
\end{tabular}

Table 8. The DEA score changes by clubs before and after 2010-2011 season 


\begin{tabular}{|lll|}
\hline & Upper 50\% in Efficiency (Before) & Lower 50\% in Efficiency (Before) \\
\hline $\begin{array}{l}\text { Upper } 50 \% \text { in } \\
\text { Efficiency (After) }\end{array}$ & $\begin{array}{l}\text { Everton, Manchester United, } \\
\text { Chelsea, Arsenal, }\end{array}$ & Manchester City \\
\hline $\begin{array}{l}\text { Lower } 50 \% \text { in } \\
\text { Efficiency (After) }\end{array}$ & Liverpool & $\begin{array}{l}\text { Aston Villa, Fulham, Sunderland, } \\
\text { Tottenham Hotspur }\end{array}$ \\
\hline
\end{tabular}

Table 9. Countries with the most international players and their playing time status in the five major European leagues for the $2006 / 07$ season

\begin{tabular}{|llll|}
\hline & $(1)$ & $(2)$ & $(3)$ \\
\hline Germany & 22.4 & 21.6 & 60 \\
\hline Italy & 24.4 & 24.8 & 92 \\
\hline Spain & 26.8 & 24.8 & 74 \\
\hline France & 25 & 25.5 & 59 \\
\hline England & 24.1 & 22.8 & 67 \\
\hline Brazil & 23.8 & 22.7 & 61 \\
\hline Argentina & 22.2 & 23.7 & 50 \\
\hline & & & \\
\hline
\end{tabular}

Notes. This table is adopted from Poli (2009) and (1) means average number of league matches played by international players at the top five clubs in the five major leagues, (2) means (2) average number of league matches played by all international players and (3) means international players playing in the five major European leagues.

\section{Figures}




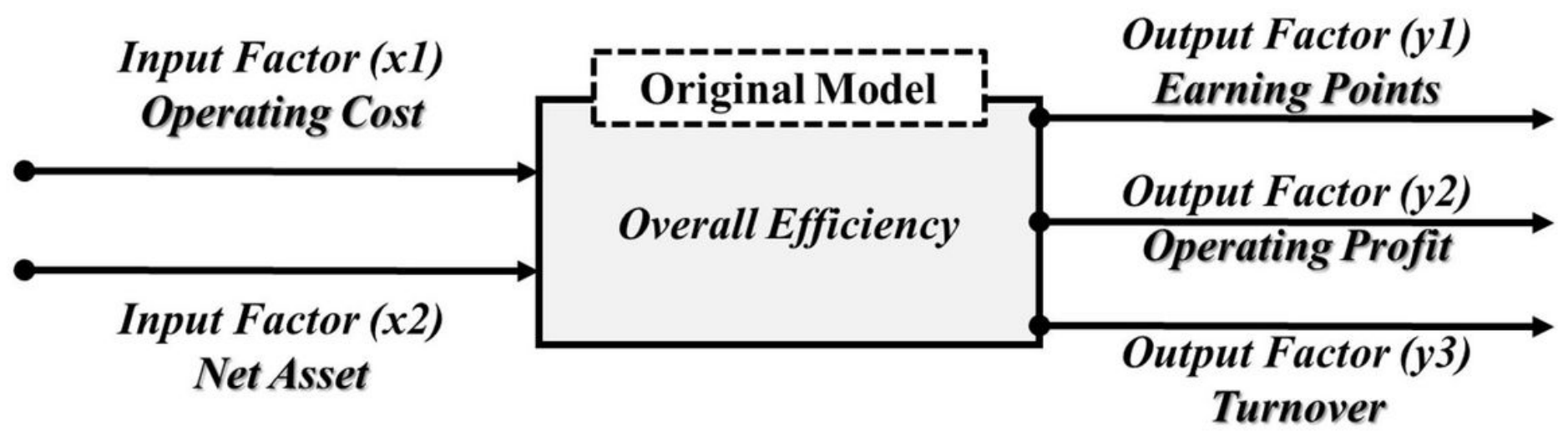

Figure 1

Description of the original model.

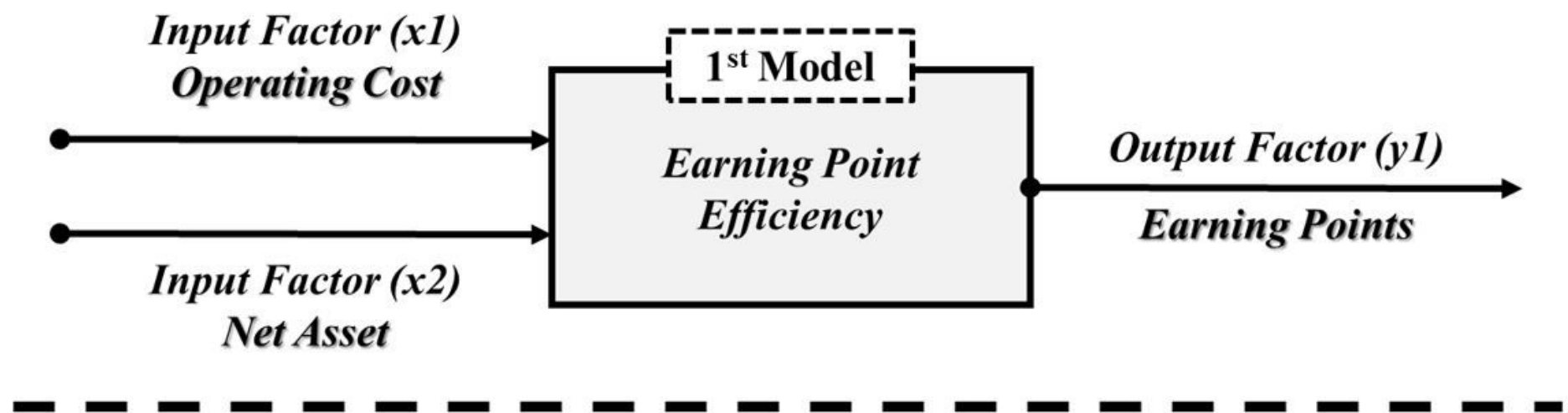

Input Factor (x1)

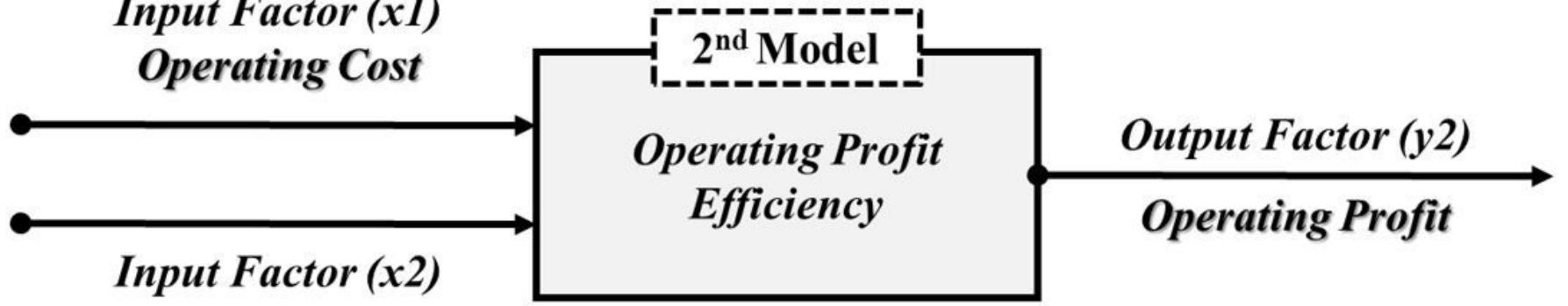

Net Asset

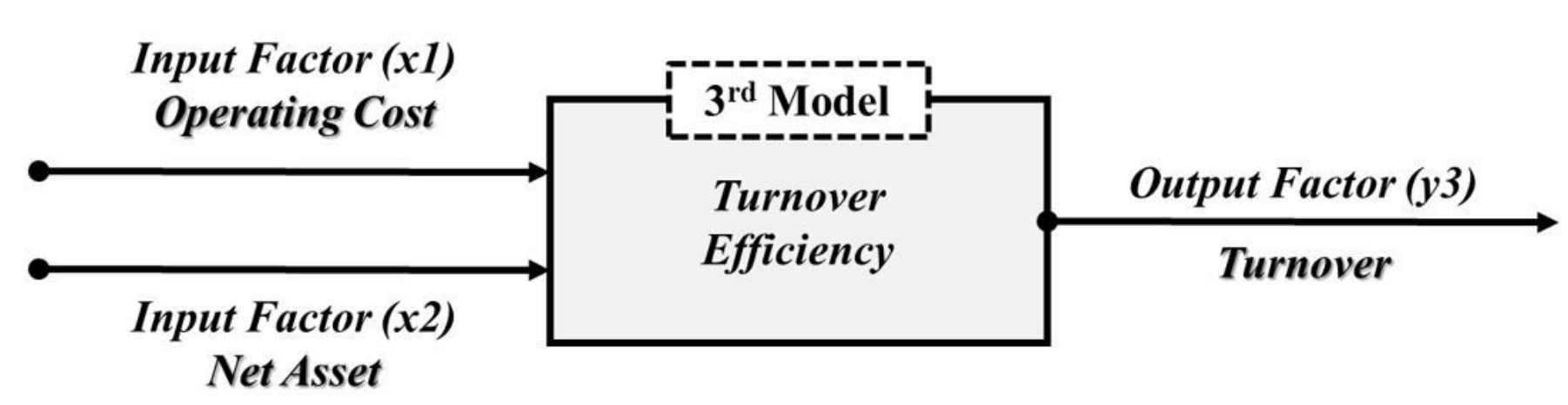

Figure 2 


\section{Pairwise Comparisons of Model}

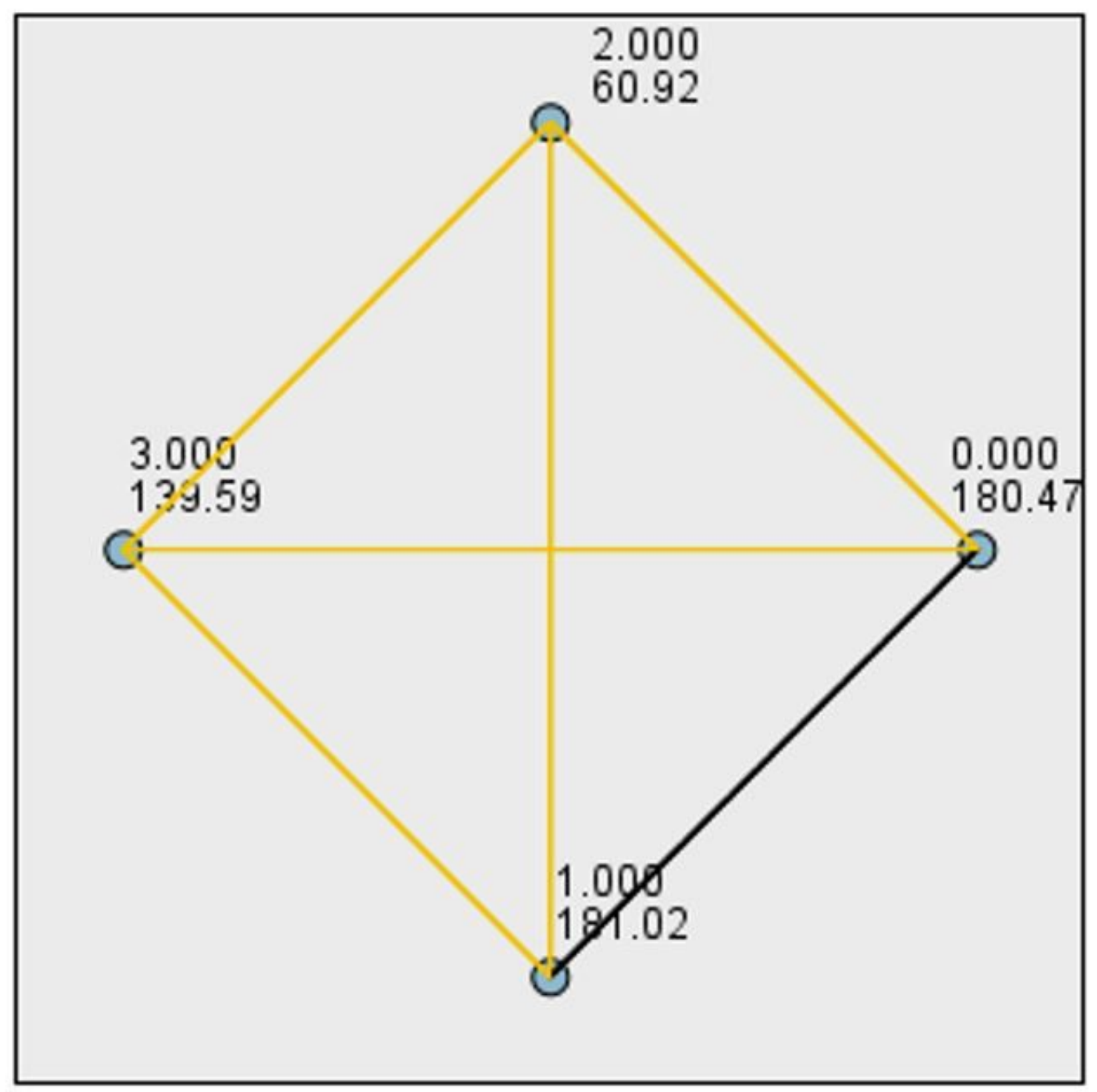

Figure 3

Result of the Pairwise comparisons between original model and revised models 0.000 : Original model (Overall efficiency) 1.000: 1st model (Earning point efficiency) 2.000: 2nd model (Operating profit efficiency) 3.000: 3rd model (Turnover efficiency) 


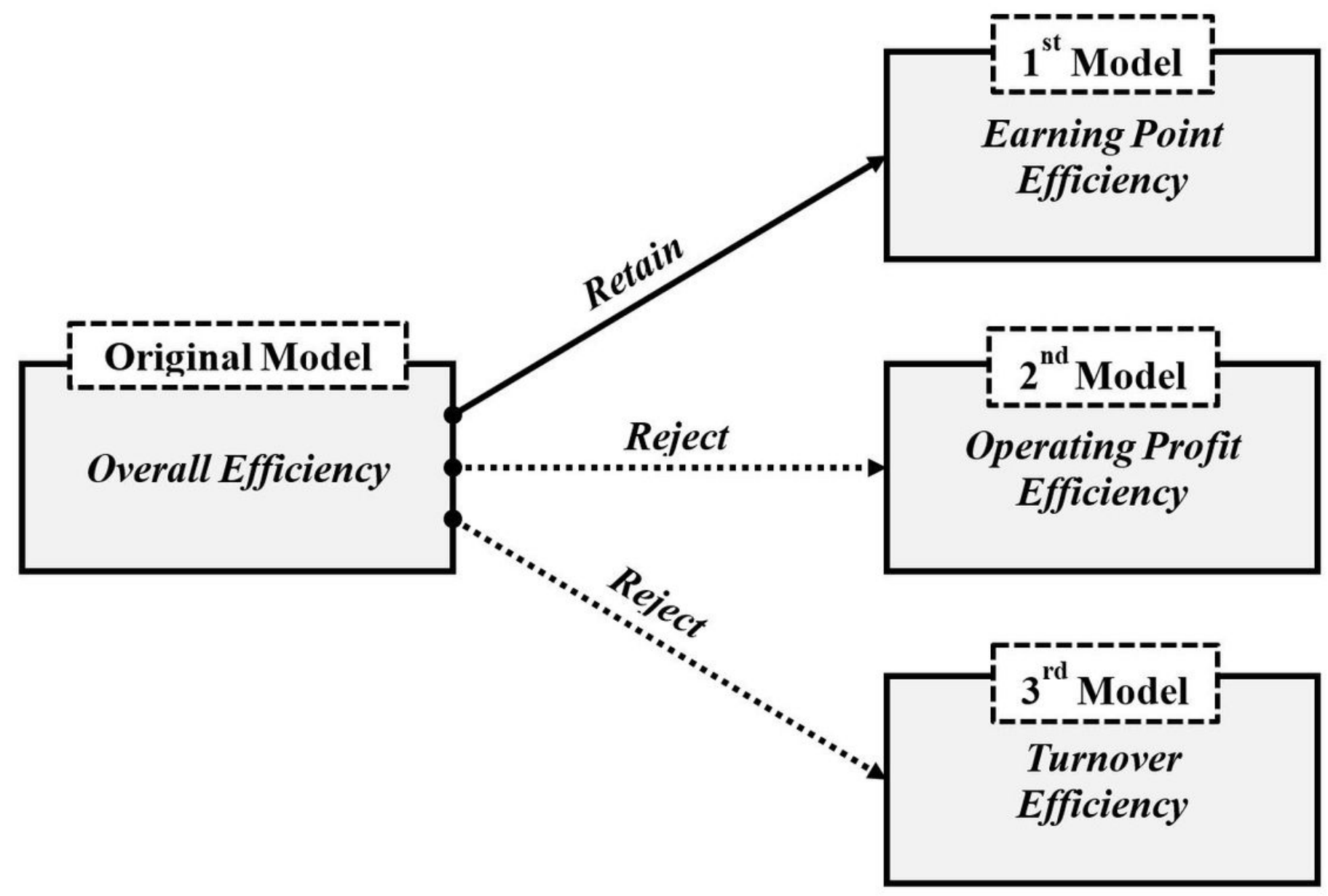

Figure 4

Acceptance and rejection of the models based on the statistical test. 
1.1000

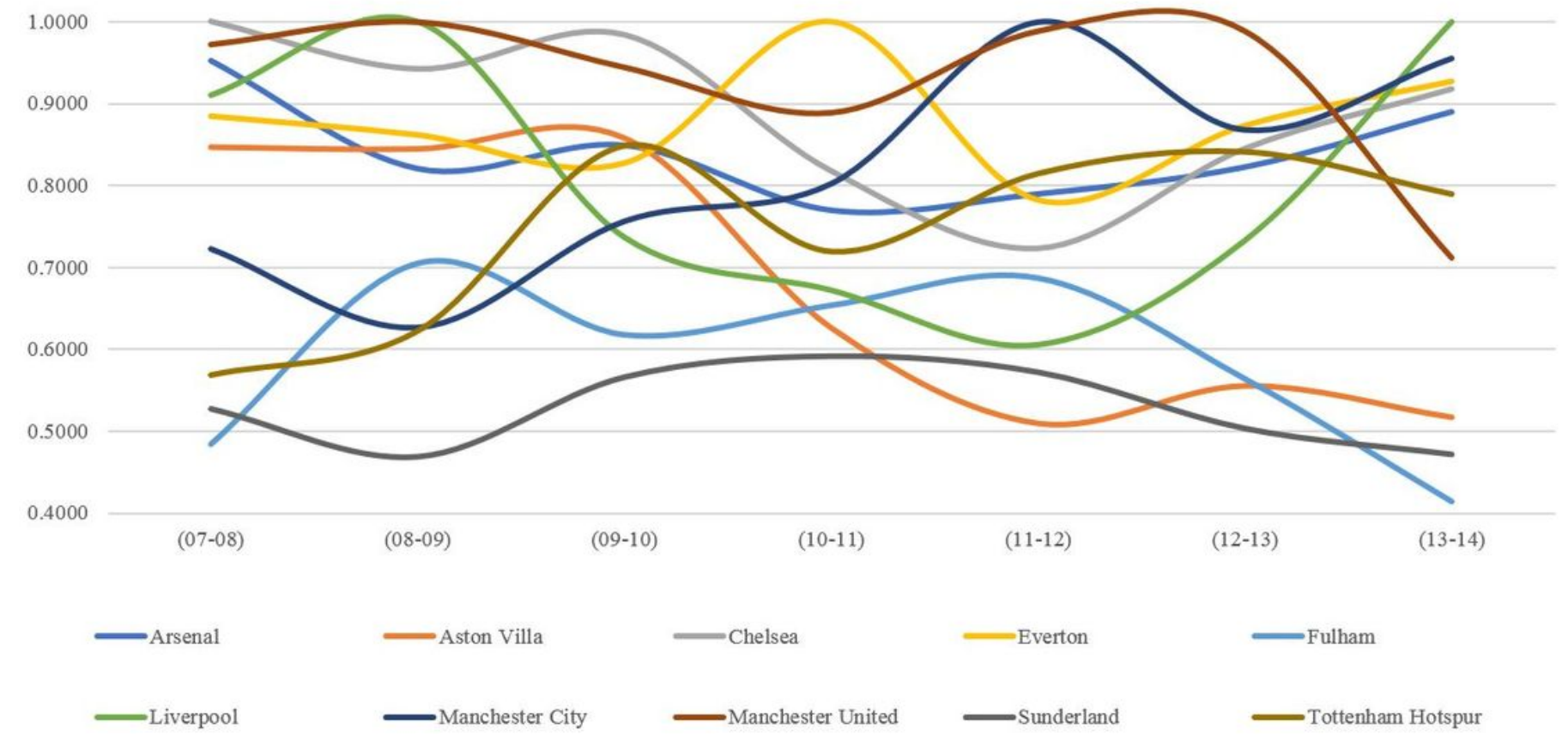

Figure 5

Result of the DEA scores before and after the Home-Grown regulation 


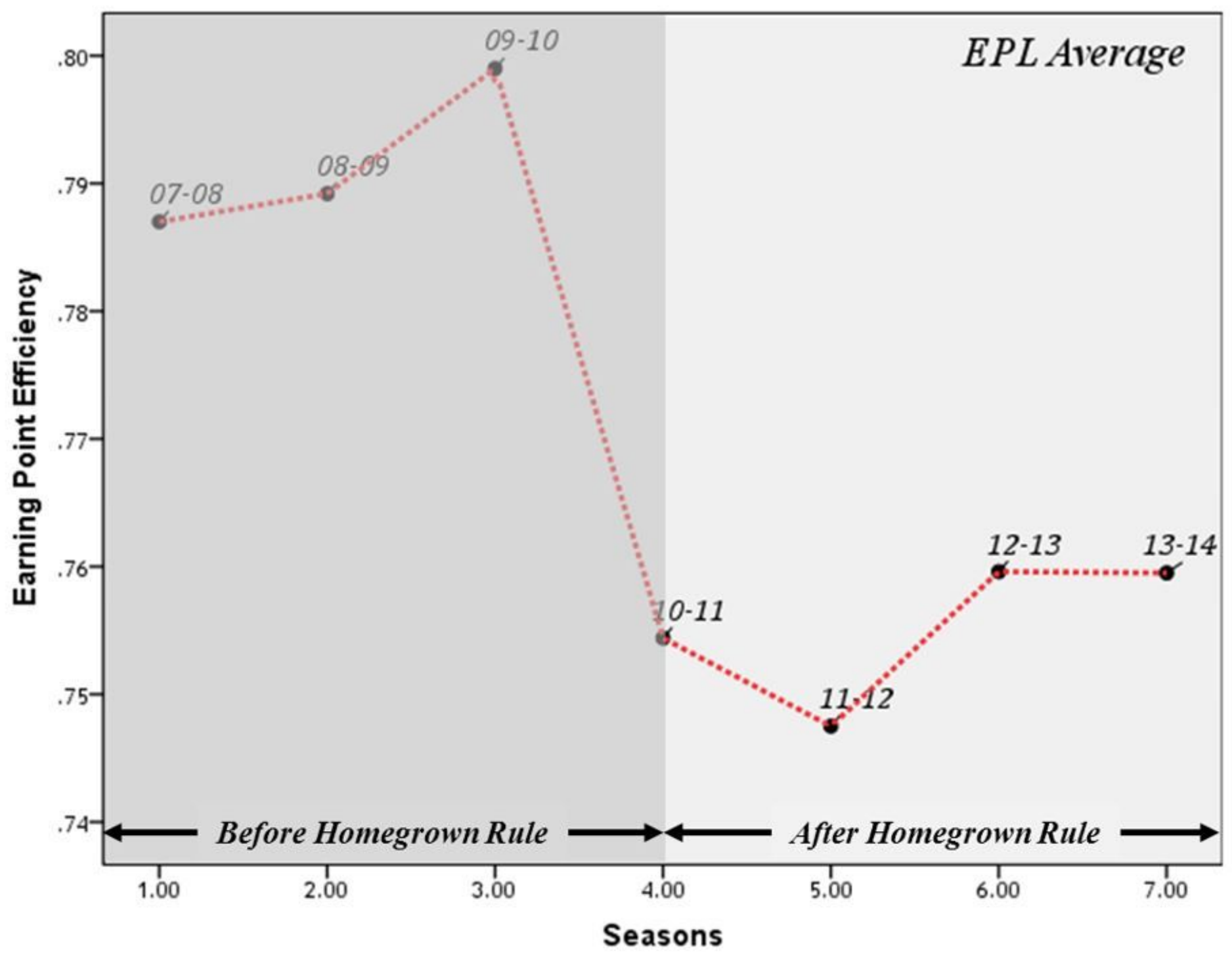

Figure 6

Result of fluctuating change before and after the implementation of Home-grown regulation (average score) 

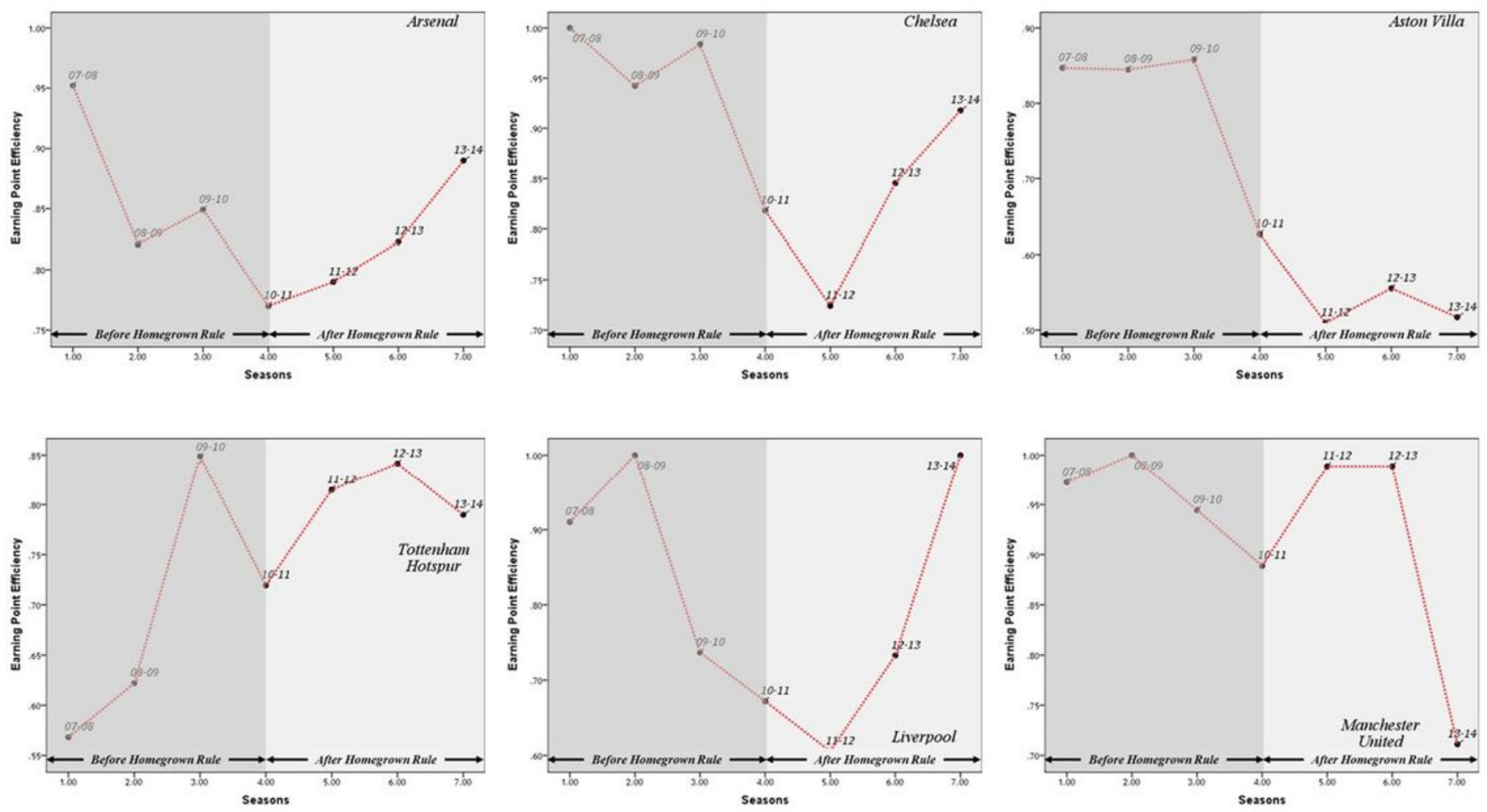

Figure 7

Clubs that shows significant drop in efficiency in 10-11 season. 

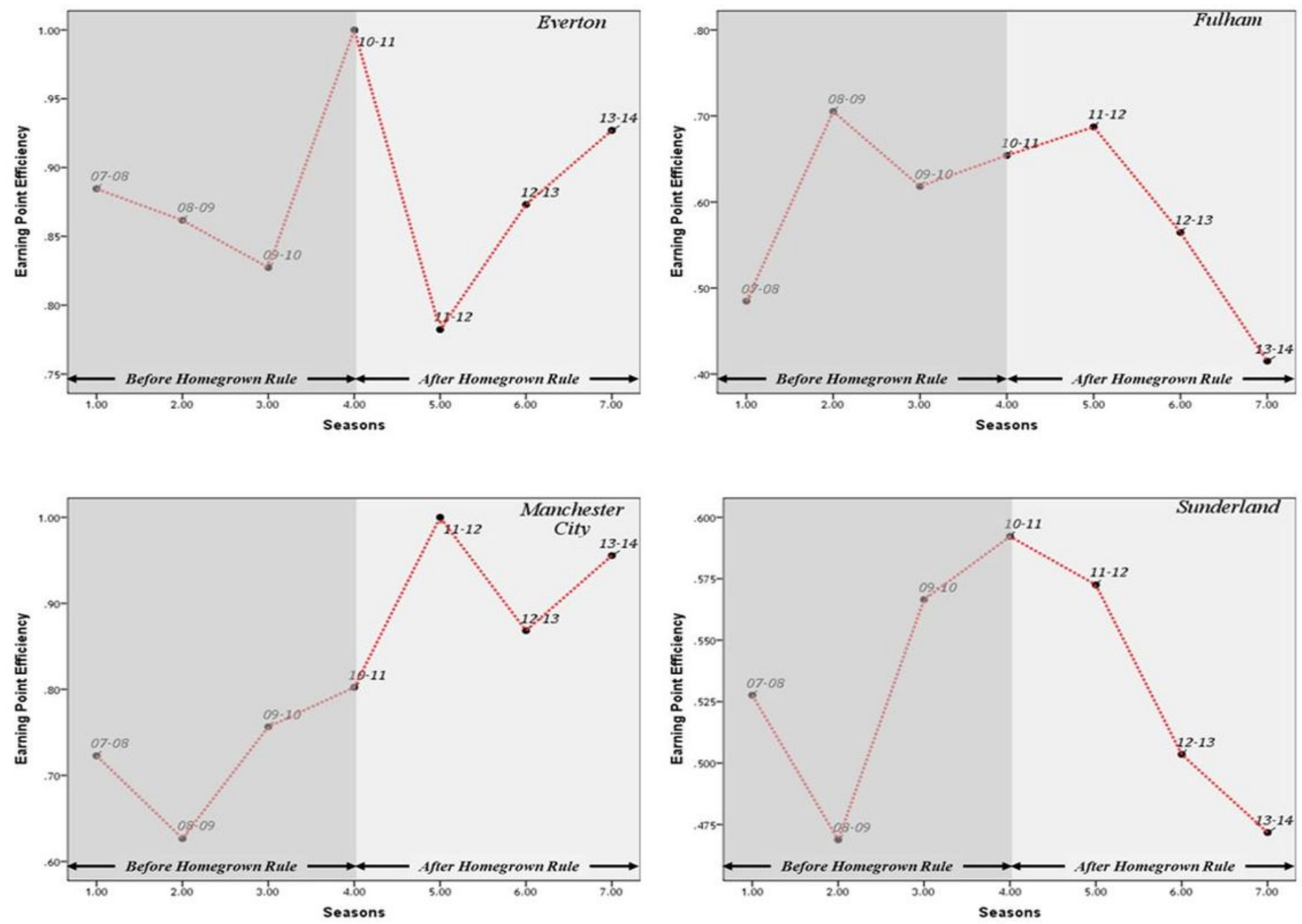

Figure 8

Clubs that show different patterns in regards to implementation of Home-grown regulation 